\title{
From Eco-Tourism to Ego-Tourism: Fluctuations in Human View on Nature over Time
}

\author{
By Sandra M. Granquist ${ }^{*}$, Per Åke Nilsson ${ }^{\dagger}$, Anders Angerbjörn ${ }^{\star}$
}

\begin{abstract}
Human view on nature has fluctuated over time, depending on contemporary knowledge and beliefs. In recent centuries, the view has shifted from an instrumental to an existential apprehension of nature. This development has contributed to the emergence of nature-based tourism. By using nature-based tourism as an example, we explore trends and tendencies concerning use and views of nature. Today, it is regarded politically correct to consider nature based on ethical standpoints deriving from scientific research results, which have been addressed as cornerstones to cope with negative anthropogenic effects on nature. However, concurrently with the emerging existentialism and individualism in society, these ethical standpoints have been questioned, which can potentially create a trend where people act against political correctness. We explore how this affects the human view on nature, and debate the emergence of a trend towards a more individualistic consumptive naturebased tourism, called ego-tourism, as well as how this trend may affect tourism and wildlife conservation.
\end{abstract}

Keywords: Eco-Tourism, Ego-Tourism, Wildlife Conservation, Political Correctness, Nature.

\section{Introduction}

Throughout the last five centuries, views on nature have fluctuated between an instrumental and utilitarian apprehension or an existential and idealistic apprehension, depending on contemporary established knowledge and beliefs (Adey 2010, Atkinson 1991). During medieval times, nature was often considered from an instrumental, quantitative, point of view as something to use for own profit or own comfort (Arler 2003, Burkart and Medlik 1990). The usefulness was often measured by size of area, vegetation, animal livestock and access to game animals, or its applicability to commercial activities (Briassoulis 2002). In recent times, a more or less existential apprehension of nature has instead developed among people (Towner 1996). During the modernist era of the $20^{\text {th }}$ century with its positive views on the never-ending improvement of human development, further efforts were taken to merge the instrumental and existential views on nature (Urry 1990). Individuals with a qualitative view on nature often build their attitude on existential assumptions, like impact of nature on well-being of the visitors (Bredesdorff 1975, Walton 2009). The existential attitude towards nature was

\footnotetext{
*Senior Researcher, Marine and Freshwater Research Institute, \& Head of Department, The Icelandic Seal Center, Iceland.

${ }^{\dagger}$ Associate Professor, Hólar University College, Iceland.

tProfessor, Department of Zoology, Stockholm University, Sweden.
} 
later criticized by resistance groups claiming that attitudes should not only be based on human convenience, but also on scientific research results regarding how to preserve nature for the future. These arguments were performed, embodied and enacted across different political and cultural contexts, and are today labelled as political correctness (Coccossis and Mexa 2004, Eber 1992).

In this article we explore fluctuations in human views on nature based on contemporary knowledge and beliefs by using nature-based tourism as a setting. The human view on nature has changed, from a scenario when humans were considered to dominate nature to a new scenario where nature dominates humans in the sense that individuals are expected to consider the importance of preserving nature. In recent times, environmental awareness has increased in importance in society in general, which also affects nature-based tourism. It is regarded politically correct to view nature based on ethical standpoints deriving from scientific research results. These standpoints should be considered as cornerstones to cope with negative anthropogenic effects on nature, for example in nature-based tourism settings. A large responsibility is put on each individual regarding environmental friendliness and concurrently with the emerging existentialism and individualism in the society, ethical standpoints have been questioned, which can potentially create a trend where people act against political correctness. The aim of the paper is to investigate how the changing view on nature may form a personal feeling of being an outsider concerning the attitude towards nature. By using nature-based tourism to exemplify the scenario, we endeavour to identify why not everyone follows what is currently considered as politically correct in society and/or what is suggested by contemporary research findings regarding how nature should be treated. The paper is organized in three sections. Firstly, changes in human attitudes towards nature historically and in recent times are reviewed, with a focus on nature-based tourism. Secondly, we outline possible reasons why people don't recognize recommendations on how to treat nature based on ecological research findings and debate possibilities of an emerging egotourism trend. The final section concludes our findings.

\section{Literature Review}

\section{Background}

The normal relation to nature during medieval and early modern times was a conception of something frightening and inhuman, underpinned by the Christian view that nature was something given by God to man for optional use (Davidson and Spearritt 2000, Dowden 2000, Giddens 1985, Towner 1996). Nature-based tourism was not practiced during ancient times. Instead, tourism was manifested by three other objectives: health by visit to mineral wells, faith by pilgrimage to sacred places, and pure curiosity (Kapuscinski 2005, Ousby 1990). 
This instrumental view on domesticated nature continued during the $16^{\text {th }}$ and $17^{\text {th }}$ centuries (Figure 1), but during the romantic $18^{\text {th }}$ century, nature instead became regarded as a place where people could rest and find themselves and where it was possible to "see God on his back" (Linné 1735). The first sign of that shift in significance was the concept civilization as an urban lifestyle where wilderness became something ennobling (Rousseau 1762). Between the $17^{\text {th }}$ and $19^{\text {th }}$ centuries, the focus of travelling shifted scholastically from being an opportunity for discourse to enthusiasm for "eyewitness" observation of nature and wilderness (Adler 1989). This existential feeling of nature was found in more or less remote places, but for convenience nature was also brought into cities in the form of parks during this time, offering an escape from civilization without leaving town. For upper- and middle-class people it was however, possible to afford a place outside town to go to during the summer months. These romantic views were common until the end of the $19^{\text {th }}$ century and in many ways, tourism became regarded as equal to a visit to nature (Adey 2010).

The definite breakthrough of nature-based tourism emerged in the 1930s due to the successfully enforced paid vacations for employees. Together with new transport possibilities like bicycle and car (Pearce 1989), a new type of tourism - pleasure-seeking - appeared, where nature became a place for amusement and discovery (Walton 2009). The real democratization of tourism by charter made it possible also for people outside the upper-classes to leave home for holiday (Adey 2010). During the first half of the $20^{\text {th }}$ century, positivism, with its focus on experience, was seen as the principle tool to achieve knowledge, especially concerning nature status and development (Comte 1842, Kuhn 1962, Piore and Sabel 1984, Schumpeter 1942). This resulted in a new trend in society, modernism, with its optimistic belief that the children of today will be better off as adults than their parents. Participation in cultural heritage was claimed to be a basic human right (Boniface 1995, Cohen 1988) and nature became a similar right for everybody to experience, although not labelled as a heritage (Butler 1991).

\section{Nature Predicament: Use and Preserve}

During the last decades of the $20^{\text {th }}$ century, the modernist era with its collectiveness had changed to a more individualistic view on life where responsibility of actions shifted more or less from authorities, such as the state and municipalities, to the individual citizen (Derrida 1967, Foucault 1972, Lyotard 1984). New concepts emerged on the agenda like social capital and human resources, with a focus on the individual (Burt 1997, Coleman 1990, Gibson 2006, Lin 2001, Putnam 1993). This shift in responsibility from authorities to individuals also concerned the environment and, consequently, nature-based tourism (Lickorish 1991, Lindberg et al. 2001). Concurrently, the awareness of potential anthropogenic effects on the environment became more evident and a general radical concern for the future of the earth developed in society (Carson 1962, Green et al. 1990). As an example, the think tank Club 
of Rome presented a manifest in 1972 called Limits to Growth stating that prevalent negative trends will create a disastrous situation for the globe if nothing is done concerning four central issues: shortage of raw materials, uncontrolled population increase, finite amount of energy sources, and an exploding waste problem (Meadows et al. 1972).

In line with the general trend in environmental awareness, the negative impact of tourism became increasingly overt (Boissevin 1996, Deaden and Harron 1994, Hunter 1997) and hence affected the ideology of how to manage nature-based tourism (Figure 1). The new policy was labelled "use and preserve". This environmentally based discourse on tourism revolves around how to balance use and protection of nature in a sustainable way which preserves both natural and socio-cultural capital, but also satisfies the needs of tourists (Farell 1992, Hunter 1997, Ko 2001). Even if this act of balance exists in overarching views, e.g. that nature is a privilege that has been given to us and that the wellbeing of the environment is important, it may be controversial to bring about responsibility on an individual level to both using and protecting nature at the same time. A prerequisite for successful implementation of such an arrangement is reciprocal understanding from both users and protectors (Ballantyne et al. 2009, Budenau 2007, Fennel 2013).

\section{Tourism Development: A Major Threat to the Globe}

One conclusion of the Club of Rome panel discussions was that the human living space, the biosphere, with its inclusion of all forms of life on earth, is limited. It was stated as something that should not be looked upon as a static condition but changing over time, a movement towards something inevitable and occasionally undefined (Meadows et al. 1972). This plastic capacity of the biosphere, regarded as something with positive consequences during the modernist era (e.g. Nicolis and Prigogine 1989, Piore and Sabel 1984), has during the recent decades instead become considered to head in disastrous directions (Buchner 2009).

The depressing news from the Club of Rome was followed up at a world conference in Rio de Janeiro twenty years later, prepared by UN. The documentation from the conference is called Agenda for the 21st century or simply Agenda 21. The commission stated that the problems mentioned by the Club of Rome as manageable, could now be considered as almost insurmountable climate problems for the world rulers during the next century. It would not be possible to offer reasonable living conditions to the next generations unless extraordinary undertakings were made, most of them inconvenient for mankind. It became everyone's concern to contribute to the development of the world's capacity to host its population (The UN World Commission on Environment and Development 1991).

The number of tourists increased globally from 200 million arrivals in 1975 to 1,4 billion in 2019 (UNWTO News 2019). Despite awareness of the consequences of the number of tourists, post-modernism fostered the same longing for escapism as during the romantic era (Gmelch 2003), fleeing 
ordinary daily life to escape to a "neutral" place where nature offers fresh air, clean water and untouched waterholes (Jacobsen 2011). Following the increased awareness of anthropogenic effects on the environment, a contribution from tourism became regarded as necessary to help solve these problems not only for maintaining cultural heritage (Boorstin 1961, Turner and Ash 1975), but also as a reduction of the threat to the environment (Buzard 1993, Hammit and Cole 1998). The concept of eco-tourism developed during the nineties and was defined frequently by multiple authors. An early definition was put forward by the Ecotourism Association of Australia (1992) as "ecologically sustainable tourism that is protecting the natural environment and encouraging understanding, appreciation and conservation of cultural elements". More recent definitions often also included the terms education, ethics, impacts and local benefits (Fennell 2001). Further, since clean water and undamaged nature are not endless commodities, the concept alternative tourism developed and was, at this time, launched as a sustainable method for visiting nature by balancing use and maintenance (Atkinson 1991, Mose 1998, Smith and Eadington 1992). It resulted in a lot of various concepts such as hiking, mountain trekking, biking and canoeing (Boissevin 1996, Nilsson 2002).

In the context of nature-based tourism, attempts to reach an equilibrium between using and protecting have included research on how to disseminate knowledge from academia (deriving from disciplines such as biology and tourism science) to society. As an example, wildlife watching tourism is known to sometimes have detrimental effects on wild animal populations. However, if equilibrium between using (watching) and protecting the animals can be obtained, wildlife watching has a potential to facilitate satisfaction for both tourists and the wildlife (Carney and Sydeman 1999, Cassini 2000, Christiansen et al. 2010, Fennel and Ebert 2004, Granquist and Sigurjónsdóttir 2014). A way to cope with the problem has been to use teleological (explanatory) instead of ontological (banning) approaches, where reasons for why behaviour can have detrimental effects have motivated tourists to behave appropriately (Granquist and Nilsson 2016, Marschall et al. 2016). Even if not all visitors follow explained recommendations, the concept has the potential to generate a tolerable situation.

In the context of wildlife tourism, different views on values of animal species can complicate the attempt to reach equilibrium between using and protecting nature. Consequently different situations require divergent solutions, sometimes contradictory to each other (Curtin 2005, Nilsson 2012). In some cases, a given species is considered an essential resource for mankind by some, while others consider the species absolutely non-consumptive. An example is the situation in Iceland, where whale watching is a large industry in the same area as whaling occurs, which has created ethical discussions in the society (Burns et al. 2018). The trophy hunting tourism industry in Africa is another example of a complex scenario. Although the industry has frequently been claimed to have good intentions for wild animal conservation as well as for locals due to economical contributions and creation of new jobs associated 
with the industry, trophy hunting tourism has also been criticized. Recently, Humane Society International pointed out that the claimed economic and conservation benefits of the trophy hunting tourism industry is exaggerated (Murray 2017). Further, in some cases, animals are harvested based on their expression of secondary sexual traits such as horns or antlers. Since there may be a correlation between expression of these traits and the individual animal's overall fitness, selective harvest of males with the largest secondary sexual traits can lead to extinction in otherwise resilient animal populations (Knell and Martinez-Ruiz 2017). Sometimes wild animals, such as lions, are bred with the sole purpose of trophy hunting by foreign tourists, which has created further ethical discussion. Barham (2013) described this type of hunting as "canned hunting" (Barham 2013).

These ethical standpoints differ from a romantic view where nature just functions as a stage where people can perform on their terms, to a view where nature deserves to perform on its own terms and conditions (Bramwell and Lane 2011, Brouder 2013, Böhm and Pfister 2011, Redpath et al. 2015).

\section{Despising Political Correctness}

Conservation, biosphere and ethics are well-defined concepts within natural science, and they reflect an accepted view among scientists in questions concerning ecology (Beaumon e al. 2008, Boncoeur et al. 2002, Coccossis and Mexa 2004, Dodds et al. 2010, González and Bello 2002). However, there is no consensus concerning the individual human responsibility for the future of the environment, as most stakeholders both within and outside the tourism industry are supposed to take some responsibility (Granquist 2016, Ioannides and Petridou 2015, Mäkitie and Ylisirniö 2013). This may create uncertainty and a lack of confidence regarding how to act, or in some cases even cause arrogance towards the approach recommended by scientists. One rather influential opinion, adhere to an approach of political incorrectness (Bridges and Wilhelm 2008, Hughes 2013). This group may deny facts accepted by scientists, even if there are adducing examples proving scientists right. Studies from the USA show that this occurs not only among poorly educated people but also in scientific surroundings and it is possible to deny even proven facts if they are contrary to own conception (Garrett 2006, Jarrick 2017, Nyhan et al. 2017). A typical argument could be: "The environmental benefits of using fossil fuels far outweigh the risks. Fossil fuels don't take a naturally clean environment and make it dirty; they take a naturally dirty environment and make it clean" (related in Epstein 2014).

Consequently, it is not astonishing when some tourists despise political correctness on purpose. They see nature as a place to which all are entitled for recreation and amusement and/or have a desire to demonstrate repudiation of the importance of nature. Nature itself becomes considered as something that stands in the way of their freedom (Ankre 2007, Lindsey et al. 2007). This political incorrectness is currently found when describing politics (Wierlemann 2002), 
describing gender discrimination (Willis 1992) and as a tool for right wing protesters (Weigel 2016).

\section{Methodology and Findings}

In the following section of the paper, we investigate how the recent increase in environmental awareness in society, which has subsequently led to an expectation that the individual takes on responsibility of being environmentally friendly, potentially can affect individual opinions. We endeavour to identify why not everyone wants to follow what is currently considered as politically correct in society regarding human view on nature and/or what is suggested by contemporary research findings. Different reasons are summarized and naturebased tourism is used to exemplify the phenomenon. Further, attempts are made to predict possible consequences for the emerging trend.

Why does Failure to recognizing Guidelines Derived from Scientific Findings occur?

Today, it is regarded politically correct to apply a nature based approach to ethical standpoints deriving from scientific research results. Individuals are expected to take most of the responsibility in being environmentally friendly. In a nature-based tourism setting, this can for example revolve around following guidelines, using ecofriendly ways of travelling, etc. In some cases, there are specific "codes of conduct" to recommend how tourists should behave to reduce anthropogenic impacts on nature and wildlife (Öquist et al. 2018) However, within the tourism research literature, authors often find that not everyone follows such expectations. There may be several reasons why not everyone behaves in accordance with contemporary research findings. In Table 1 , we list four possible causes for not recognizing recommendations based on findings deriving from ecology research. Firstly, individuals may consider it to be their ,right" to visit nature, a right that can be compared to the right to take part in their cultural heritage. The opinion within this group is that recommendations on optimal access to nature given by ecologists based on scientific research should not be superior to this right. Hence, the right to enjoy nature is prioritized before the need to consider preservation actions. A second reason for acting against what is considered correct is lack of knowledge in the subject. This often stems from failure in disseminating scientific knowledge from academia to society in a pedagogic way. People who are not aware of how and why actions and decisions affect the environment can be less likely to act accordingly to what is considered right based on scientific findings. Other people may, although being aware of what is considered right based on scientific knowledge, lack confidence in scientific findings and disagree with research methods or claim that biases exists in research methods. However, lacking knowledge or disbelieving in scientific findings does not out rule that these groups have a positive attitude towards preserving nature. Furthermore, 
in a fourth group, some generally dislike the idea of political correctness enough to wilfully disobey such conventions despite understanding and sometimes even agreeing with research-based conclusions. As postmodernists, they are fostered to put greater importance on their ego (Table 1).

Table 1. Four Possible Causes to not recognizing Recommendations of how to Treat Nature Based on Ecological Research Findings

\begin{tabular}{|c|c|}
\hline Possible Causes & Definition \\
\hline \multicolumn{2}{|l|}{ My right } \\
\hline $\begin{array}{l}\text { The right to access nature } \\
\text { heritage }\end{array}$ & $\begin{array}{l}\text { Individuals consider it to be their "right" to visit nature, a right } \\
\text { that can be compared to the right to take part in the cultural } \\
\text { heritage. Recommendations on optimal access to nature given } \\
\text { based on scientific research should not be superior to this right }\end{array}$ \\
\hline \multicolumn{2}{|l|}{ Lack of knowledge } \\
\hline $\begin{array}{l}\text { Lack of education or } \\
\text { problems in disseminating } \\
\text { scientific knowledge to } \\
\text { society }\end{array}$ & $\begin{array}{l}\text { Individuals lack understanding of what is considered "right". This } \\
\text { can stem from failure in disseminating scientific knowledge to } \\
\text { society in a pedagogic way. Not following recommendations in } \\
\text { this case is unconscious }\end{array}$ \\
\hline \multicolumn{2}{|l|}{ Wrong knowledge } \\
\hline $\begin{array}{l}\text { Disbelief in findings } \\
\text { derived from ecology } \\
\text { research }\end{array}$ & $\begin{array}{l}\text { Individuals do not believe in scientific findings that are the } \\
\text { foundation of a recommendation }\end{array}$ \\
\hline \multicolumn{2}{|l|}{ Political incorrectness } \\
\hline $\begin{array}{l}\text { General objection to } \\
\text { political awareness }\end{array}$ & $\begin{array}{l}\text { Individuals objects to what is considered as politically correct due } \\
\text { to a desire to demonstrate repudiation of the importance of nature }\end{array}$ \\
\hline
\end{tabular}

\section{From Eco-Tourist to Ego-Tourist?}

The concept "ego-tourist" was first introduced in 1993 and defined as a tourist who wants to travel in a way that contributes to his/her ego enhancement (Wheeller 1993, Wheeller 1994). Later, the concept was connected to rich or famous people who visit pristine places pretending to care about the environment but only staying at hotels in urban areas (Dann 1977, Munt 1994). There has been an attendant shift away from the traditional mass-packaged holidays, to tourism that fit within the exciting and adventurous lifestyles of the new middle classes (MacCannell 2002). While mass tourism has been regarded as shallow and degrading experiences, ego-tourism practices, based on the above definition, have been viewed benevolently and few critiques have emerged (Wheeller 2005). Another definition was put forward by Perkins and Brown (2012). They describe eco-tourists as people with high biospheric values, with a focus on an intrinsic worth of nature, having a high interest in tourism specific pro-environmental attitudes and commitment to environmental protection. The opposite of high biospheric values would, according to Perkins and Brown (2012), be high egoistic 
values, which is found among people who have a strong self-interest and greater interest in hedonistic-type tourism, but less interest in nature tourism. People with high egoistic values also have less interest in environmental conservation and protection, hence caring more about their own experience than the ecosystem (Perkins and Brown 2012).

As discussed above, the indication of an increasing number of people questioning political correctness supplements the view on ego-tourism by changing the motives behind it. It is not only upper-class tourists who want to see pristine nature but also ordinary people. What connects them is repugnance towards political correctness and a desire to be free to do what they want without allowing nature to dominate their actions (Briassoulis 2002, Brown 2015, Granquist and Nilsson 2013, Moffit 2016, Urbinati 2014, Wheeller 2007). Based on the findings in the present article, as a result of these divergent views and opinions, an "ego-tourism" trend may emerge (or already has), with tourists claiming the "right" to nature both as heritage but also that nature should be available for humans without restrictions (Figure 1). Another reason for an ego-tourist approach is lack of understanding of scientific research findings, or absence of confidence regarding those findings obstructing free access to nature. This underlines the importance of proper dissemination of scientific findings to the society (Granquist and Nilsson 2016, Marschall et al. 2016). The "correctness" of scientific findings must be processed in a way that is understood and accepted, something which seems to be more delicate than scientists and authorities often expect.

The view on nature has shifted over time from regarding nature as something evil to something that defines the essence of life; from something available to consume for development or amusement and finally to something that has to be preserved from human interference. Eventually, this development seems to show a retrograde in dominance where nature, which historically was controlled by human, is now dominating human everyday life (also comprising nature-based tourism) in terms of expectation of environmental preservation. A trend towards a more individualistic consumptive use, ego-tourism, could be a result which in turn would have unforeseeable future consequences (Figure 1). The horizontal axis indicates how humans have utilized nature resources; from consumption during the $15^{\text {th }}$ century to preservation in the $20^{\text {th }}$ century. The vertical axis shows the change in attitudes towards nature; from the $15^{\text {th }}$ century when people were frightened of nature to where people seek relaxation and amusement in the $21^{\text {st }}$ century. 
Figure 1. Human View on Nature (and Nature-Based Tourism) Change Over the Historical Time (Numbers Referring to Different Centuries)

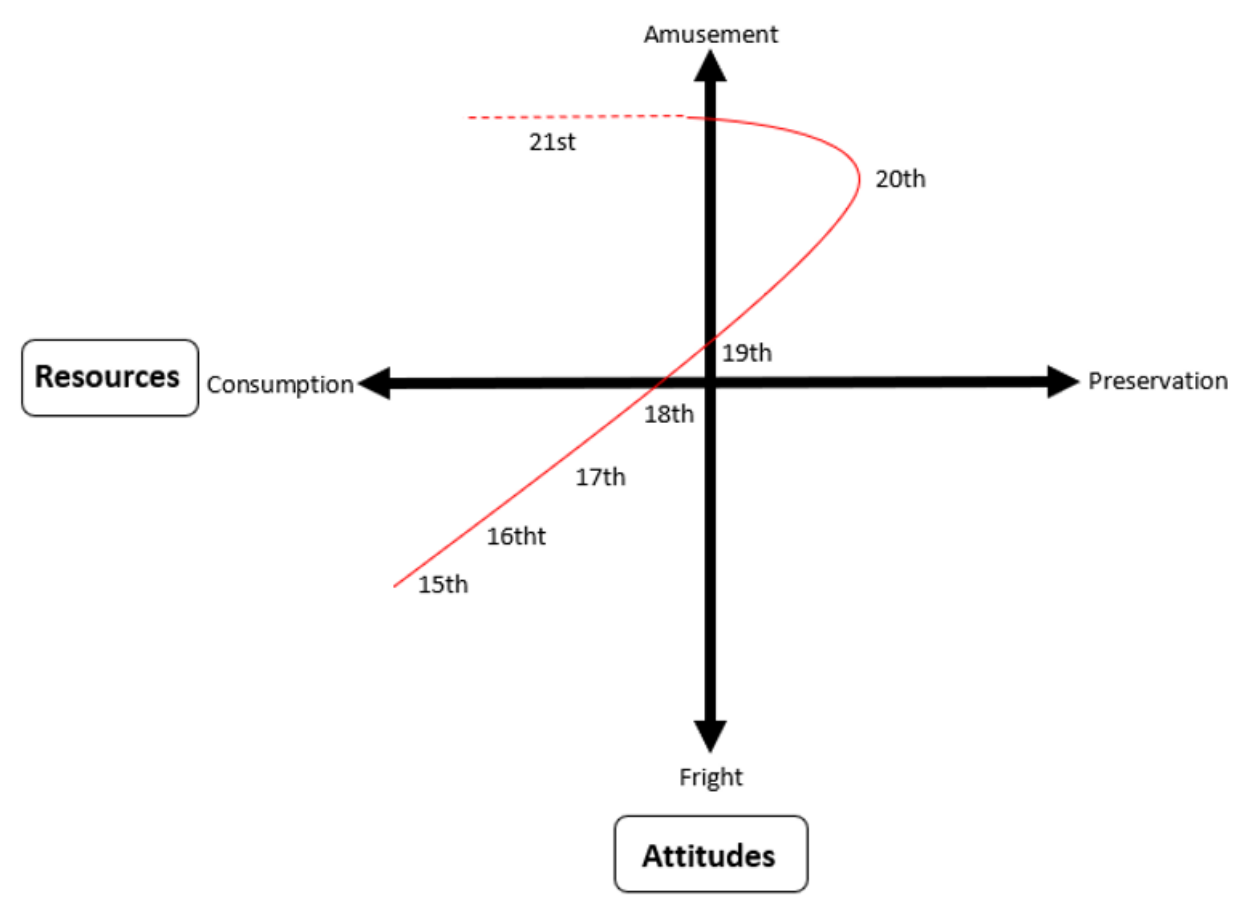

\section{Conclusions}

Methods to dominate nature in different ways were developed up to late 20th century. Concurrently with the emerging post-modernism and individualism, these methods became disunited and problems with methods to deal with nature became more complicated than before. Further, previous anthropogenic interference with nature had in fact deteriorated nature in some ways. The Rome Club and the Rio Conference first indicated and then stated clearly that human dominance over nature has turned to a situation where nature dominates human behavior and everyday life. This development has also become evident within the tourism industry.

In this paper we have reviewed fluctuations in human views on nature over time with nature-based tourism as a setting. Further, we explored how the emerging existentialism and individualism in the society potentially can create a trend where people are refraining from regarding nature based on ethical standpoints derived from scientific research, which is currently considered politically correct. The emergence of a possible ego-tourism trend as a result of this was also debated, which, although not embracing the majority of tourists, exists and the future of it is unforeseeable.

The crucial question for environmentalists will be: should this development be acknowledged and acted against, and if so, how? Is it useless to counteract political correctness or should political correctness be formulated so it can be accepted? Or is it time to be less ethically pushy and provocative? Will these 
indications regarding a more self-centered view on nature lead to a regime shift in tourism towards a wider acceptance of ego-tourism? The questions are manifold.

Many people are frustrated that nature impedes the progress of the development of society, resulting in an urge to demonstrate repudiation of the importance of nature, and further, it is still often not clear who are responsible for preserving nature. This may lead to a desire to act in opposition to what is expected according to political correctness. Post-modernists are fostered to put their ego in the center and denying fact is not unique to less educated people. Researchers have learned by observation that there is a strong will to deny research that is contrary to people's political or emotional conceptions. Climate change is now the great concern, but since nobody wants to live with the predicted effects, a dismissal of them is a common human reaction. This may foster a trend of opposition to both the message and the messenger.

Despite being based on scientific research and experience, views on conservation, biosphere and ethics are either hard to grasp or perceived as awkward or threatening to many and may be denied as a spontaneous reflex (Table 1). Environmentalists have dominated the discourse regarding conservation since the end of the last century and are obviously not prepared to accept these diverse opinions. The scenario can be compared to the identity policy, where only those belonging to an ethnic group or a gender are allowed to represent it to others, while it is often not considered politically correct for "outsiders" to have an opinion. Similarly, the views of environmental scientists on conservation, biosphere and ethics are often considered as interpretative prerogative while alternative views from outsiders are considered politically incorrect. Individuals not belonging to the scientific community may perceive themselves as being outside the political highway and therefore believe that they have a right to act as they themselves find proper, serving their own needs.

General objection to political correctness is not the only reason for not following what is recommended by scientists. In this paper we define four different causes to not behaving according to what is considered as politically correct; advocating for the right to access the natural heritage, lack of knowledge, disbelieves in scientific findings or purposely acting against what is considered as politically correct (Table 1). A major challenge would be to sort out the background for these attitudes and test, for example, how they are related to increasing knowledge on how and why a specific recommendation is presented based on scientific research. Heberlein (2012) pointed out that attitudes and behaviour, for example regarding environmental views, are typically not highly correlated. The group that advocate for "their rights" or that are "politically incorrect" will probably not change their behaviour or attitude by more knowledge. However, groups that "lack knowledge" or think that the "knowledge is wrong" may initially have a positive attitude towards preserving nature, despite acting against what is recommended based on scientific findings (Table 1). With increased knowledge and a deeper understanding, this group may change their behaviour to being less ego- 
centred, while their positive attitudes towards nature preservation would stay constant.

The possible emerging trend from eco-tourism to ego-tourism clearly calls for further research. Potential problems must be identified, and solutions deliberated. A problem could, for example, be that disagreements between locals and tourist might increase, underlining the importance of further research on the topic. We suggest that future research would profit from taking on an interdisciplinary approach involving different scientific disciplines, such as ecology and tourism research. A transdisciplinary approach, combining results from the scientific community with knowledge from stakeholders in the society such as locals, but also politicians with different agendas would be beneficial (Granquist and Nilsson 2016). Although we in the current study used nature-based tourism to exemplify and deduce fluctuations in human view on nature, our findings could possibly be used as a model for other parallel cases where human view on nature equally affects the scenario, such as in debates about whaling and large carnivore hunt and even climate change.

\section{References}

Adey P (2010) Mobility. London: Routledge.

Adler J (1989) Origins of sightseeing. Annals of Tourism Research 16(1): 7-29.

Ankre R (2007) Understanding the Visitor. A Prerequisite for Coastal Zone Planning. (Doctoral Dissertation). Blekinge Institute of Technology, Sweden.

Arler F (2003) En helt igennem demokratisk natur [A totally democratic nature]. In P Agger et al. (eds), Naturens vardi - Vinkler på danskernes forhold til naturen [Value of Nature - Views of Danes'Relation to Nature], 41-49. Copenhagen: Gads.

Atkinson A (1991) Principals of Political Ecology. London: Belhaven.

Ballantyne R, Packer J, Huges K (2009) Tourists' support for conservation messages and sustainable management practices in wildlife tourism experiences. Tourism Management 30(5): 658-664.

Barham P (2013) Canned hunting. The Guardian. Retrieved from https://www.theguar dian.com/environment/2013/jun/03/canned-hunting-lions-bred-slaughter. [Accessed 13 June 2013].

Beaumont NJ, Austen MC, Mangi SC, Townsend M (2008) Economic valuation for the conservation of marine biodiversity. Marine Pollution Bulletin 56(3): 386-389.

Böhm G, Pfister H-R (2011) Tourism in the face of environmental risks: Sunbathing under the Ozone hole and strolling through polluted air. Scandinavian Journal of Hospitality and Tourism 11(3): 250-267.

Boissevain J (1996) Coping with Tourists. Oxford: Berghahn Books.

Boncoeur J, Alban F, Ifremer OG, Ifremer OT (2002) Fish, fisheries, seals and tourists. Natural Resource Modeling 15: 387-411.

Boniface P (1995) Managing Quality Cultural Tourism. London: Routledge.

Boorstin D (1961) The Image or what happened to the American Dream. Chicago: Chicago University Press.

Bramwell B, Lane B (2011) Towards innovation in sustainable tourism research? Journal of Sustainable Tourism 20(1): 1-7. 
Bredesdorff T (1975) Digternes Natur. En Idés Historie I 1700-Tallets Danske Poesi [Poet'S Nature. The History of an Idea in the Danish Poetry of the 19th Century]. (Doctoral Dissertation). Copenhagen University, Denmark.

Briassoulis H (2002) Sustainable tourism and the question of commons. Annals of Tourism Research 29(4): 1065-1085.

Bridges CM, Wilhelm WB (2008) Going beyond green: The "why and how" of integrating sustainability into the marketing curriculum. Journal of Marketing Education 30(1): 33-46.

Brouder P (2013) Tourism Development in Peripheral Areas. (Doctoral dissertation). MidSweden University, Östersund, Sweden.

Brown W (2015) Undoing the Demos - Neoliberalism'S Stealth Revolution. Cambridge Massachusetts: MIT Press,

Buchner B (2009) Designing sustainability policy. In V Boosetti, R Gerlagh, S Schleicher (eds) Modelling Sustainable Development, 18-33. Cheltenham: Edward Elgar.

Budeanu A (2007) Sustainable tourism behaviour - a discussion of opportunities for change. International Journal of Consumer Studies 31(5): 499-508.

Burkart AJ, Medlik S (1990) Historical Development of Tourism. Aix-en-Provence: Centre des Hauts Etudes Touristiques, Aix-en-Provence.

Burns GL, Öqvist EL, Angerbjörn A, Granquist SM (2018) When the wildlife you watch becomes the food you eat: Exploring moral and ethical dilemmas when consumptive and non-consumptive tourism merge. In C Kline (ed) Animals, Food, and Tourism, 22-35. New York: Routledge Ethics of tourism.

Burt R (1997) The contingent of social capital. Administrative Science Quarterly 42(2): 339-365.

Butler R (1991) Tourism, environment and sustainable development. Environmental Conservation 18(3): 201-209.

Buzard J (1993) The Beaten Track. Oxford: Clarendon Press.

Carney KM, Sydeman WJ (1999) A review of human disturbance effects on nesting colonial waterbirds. Waterbirds: The International Journal of Waterbird Biology 22(1): 68-79.

Carson R (1962) Silent Spring. Houghton: Mifflin Company.

Cassini M (2000) Behavioural responses of South American fur seals to approach by tourists. Applied Animal Behaviour Science 71(4): 341-346.

Christiansen F, Lusseau D, Stensland E, Berggren P (2010) Effects of tourist boats on the behaviour of Indo-Pacific bottlenose dolphins off the south coast of Zanzibar. Endangered Species Research 11: 91-99.

Coccossis H, Mexa A (2004) The Challenge of Tourism Carrying Capacity Assessment. Ashgate: Aldershot.

Cohen E (1988) Authenticity and commodization in tourism. Annals of Tourism Research 15(3): 371-386.

Coleman J (1990) Foundations of Social Theory. Harvard: Harvard University Press.

Comte A (1842) Cours de Philosophi Positive [Positive Philosophy Course]. Paris: Nathan.

Curtin S (2005) Nature, wild animals and tourism: An experiential view. Journal of Ecotourism 4(1): 1-15.

Dann GMS (1977) Anomie, ego-enhancement, and tourism. Annals of Tourism Research 4(4): 184-194.

Davidson J, Spearritt P (2000) Holiday Business: Tourism in Australia since 1870. Melbourne: Melbourne University Press.

Deaden P, Harron S (1994) Alternative tourism and adaptive change. Annals of Tourism Research 21(1): 81-102. 
Derrida J (1967) La Voix et le Phénomène. [Voice and Phenomenon]. Paris: PUF.

Dodds R, Graci SR, Holmes M (2010) Does the tourist care? A comparison of tourists in Koh Phi Phi, Thailand and Gili Trawangan, Indonesia. Journal of Sustainable Tourism 18(2): 207-222.

Dowden K (2000) European Paganism. London: Routledge.

Eber S (1992) Beyond the Green Horizon: Principles for Sustainable Development. Discussion paper at the WWF conference "Tourism Concern". Godalming, Surrey.

Ecotourism Association of Australia (1992) The Ecotourism Society of Australia, Newsletter 1, 2 (1991 a, b).

Epstein A (2014) The Moral Case for Fossil Fuels. New York: The Penguin Book.

Farell B (1992) Tourism as an element in sustainable development. In V Smith, W Eadington (eds) Tourism Alternatives, 115-132. Philadelphia: University of Pennsylvania.

Fennell DA (2001) A content analysis of ecotourism definitions. Current Issues in Tourism 4(5): 403-421.

Fennel D (2013) Ecotourism. London: Routledge.

Fennel D, Ebert K (2004) Tourism and precautionary principle. Journal of Sustainable Tourism 12(6): 461-476.

Foucault M (1972) The Archaeology of Knowledge. New York: Pantheon.

Garrett F (2006) Archeological Fantasies: How pseudoarcheology misrepresents the past and misleads the public. London: Routledge.

Gibson L (2006) Learning Destinations. (Doctoral Dissertation). Karlstad University, Sweden.

Giddens A (1985) A Contemporary Critique of Historical Materialism. Cambridge: Polity.

Gmelch G (2003) Behind the Smile. Indiana: Indiana University Press.

González A, Bello L (2002) The construct "lifestyle" in market segmentation: The behavior of tourist consumers. European Journal of Marketing 36(1/2): 51-85.

Granquist SM (2016) Ecology, tourism and management of harbour seals (Phoca vitulina) (Doctoral Dissertation), Stockholm University, Stockholm.

Granquist SM, Nilsson PÅ (2016) Who's watching whom? An interdisciplinary approach to the study of seal-watching tourism in Iceland. Journal of Cleaner Production 111: 471-478.

Granquist SM, Nilsson PÅ (2013) The wild north: Network cooperation for sustainable tourism in a fragile marine environment in the Arctic region. In D Müller, L Lundmark, R Lemelin (eds) New issues in polar tourism, 123-132. Heidelberg: Springer.

Granquist SM, Sigurjónsdóttir H (2014) The effect of land based seal watching tourism on the haul-out behaviour of harbour seals (Phoca vitulina) in Iceland. Applied Animal Behaviour Science 156: 85-93.

Green H, Hunter C, Moore B (1990) Assessing the environmental impact of tourism development. Tourism Management 11(2): 119-120.

Hammit W, Cole D (1998) Wildlife Recreation. New York: John Wiley.

Heberlein T (2012) Navigating Environmental Attitudes. Oxford: Oxord University Press.

Hughes K (2013) Measuring the impact of viewing wildlife: do positive intentions equate to long term changes in conservation behaviour? Journal of Sustainable Tourism 21(1): 42-59.

Hunter C (1997) Sustainable tourism as an adaptive paradigm. Annals of Tourism Research 24(4): 850-867.

Ioannides D, Petridou E (2015) Archipelago tourism: Synthesis and reflections. In G Baldacchino (ed) Archipelago Tourism: Policies and Practices, 241-248. London: Ashgate. 
Jacobsen JK (2011) Monitoring motoring: A study of tourists' Viewpoints of environmental performance and protection practices. Scandinavian Journal of Hospitality and Tourism 7(2): 104-119.

Jarrick A (2017) Det Finns Inga Häxor [There are no Witches]. Stockholm: Weyler.

Kapuscinski R (2005) Podroze z Herodotem [On travel with Herodotos]. Warszawa: SW Czytelnik.

Ko J (2001) Assessing progress of tourism sustainability. Annals of Tourism Research 28(3): 817-820.

Knell RJ, Martínez-Ruiz C (2017) Selective harvest focused on sexual signal traits can lead to extinction under directional environmental change. Proceedings of the Royal Society B, 284, 20171788.

Kuhn T (1962) The Structure of Scientific Revolutions. Chicago: University of Chicago.

Lickorish L (1991) Developing Tourism Destinations. London: Longman.

Lin N (2001) Social Capital. A Theory of Social Structure and Action. Cambridge: Cambridge University Press.

Lindberg K, Andersson TD, Dellaert BG (2001) Tourism development. Assessing social gains and losses. Annals of Tourism Research 28(4): 1010-1030.

Lindsey PA, Roulet PA, Romañach SS (2007) Economic and conservation significance of the trophy hunting industry in sub-Saharan Africa. Biological Conservation 134(4): 455-469.

Linné C (1735) Systema Naturae. [Natural System]. Stockholm: Laurentii Salvii.

Lyotard J-F (1984) The Postmodern Condition: A Report on Knowledge. Manchester: Manchester University Press.

MacCannell D (2002) The ego factor in tourism. Journal of Consumer Research 29(1): 146-151.

Mäkitie T, Ylisirniö AL (2013) Conflicting discourses in tourism development. In D Müller, L Lundmark, R Lemelin (eds) New Issues in Polar Tourism, 163-176. Heidelberg: Springer.

Marschall S, Granquist SM, Burns GL (2016) Interpretation in wildlife tourism. Journal of Outdoor Recreation 17: 11-19.

Meadows DH, Meadows DL, Randers J, Behrens W (1972) Limits to grow. Beteshda, Maryland: Potomac Associates.

Moffit B (2016) The Global Rise of Populism - Performance, Political Style, and Representation. Stanford: Stanford University Press.

Mose I (1998) Sanfter Tourismus. [Mild Tourism]. Vechta: Verlag Fakultas.

Munt I (1994) Eco-tourism or ego-tourism? Race and Class 36(1): 49-59.

Murray CK (2017) The lion's share? On the economic benefits of trophy hunting. A report for the Humane Society International, prepared by Economists at Large, Melbourne, Australia.

Nicolis G, Prigogine I (1989) Exploring Complexity. Munic: KG Verlag.

Nilsson P-Å (2002) Staying at farms: An ideological background. Annals of Tourism Research 29(1): 7-24.

Nilsson P-^̊ (2012) Tourist Background and Local Acceptance. Akureyri, Iceland: ICTR, University of Akureyri.

Nyhan B, Skovron C, Titiunik R (2017) Differential registration bias in voter file data: A sensitivity analysis approach. American Journal of Political Science 61(3): 744-760.

Öquist LE, Granquist SM, Burns GL, Angerbjörn A (2018) Seal watching: An investigation of codes of conduct. Tourism in Marine Environments 13(1): 1-15.

Ousby I (1990) The Englishman's England. Cambridge: Cambridge University Press.

Pearce D (1989) Tourist development. Christchurch, New Zealand: University of Christchurch. 
Perkins HE, Brown PR (2012) Environmental values and the so-called true ecotourist. Journal of Travel Research 51(6): 793-803.

Piore M, Sabel C (1984) The Second Industrial Divide. New York: Basic Books.

Putnam R (1993) The prosperous community: Social capital and public life. The American Prospect 13: 35-42.

Redpath SM, Gutiérrez RJ, Wood KA, Young JC (2015) Conflicts in Conservation: Navigating Towards Solutions. Cambridge: Cambridge University Press.

Rousseau JJ (1762) Le Contrat Social. [The Social Contract]. Amsterdam: Marc Michel.

Schumpeter J (1942) Capitalism, Socialism and Democracy. New York: Harper.

Smith V, Eadington R (1992) Tourism Alternatives. Chichester: Wiley.

Towner J (1996) An Historical Geography of Recreation and Tourism in the Western World 1540-1940. Chichester: Wiley.

Turner J, Ash L (1975) The Golden Hordes: International Tourism and the Pleasure Periphery. London: Constable.

UN World Commission on Environment and Development (1991) Oxford University Press.

World Tourism Organization UNWTO News (2019) International Tourist Arrivals Reach 1,4 Billion, Issue 83. Madrid: UNWTO.

Urbinati N (2014) Democracy Disfigured. - Opinion, Truth, and the People. Harvard: Harvard University Press.

Urry J (1990) The Tourist Gaze. London: Sage.

Walton J (2009) Prospects in tourism history: Evolution, state of play and future developments. Tourism Management 30(6): 783-793.

Weigel M (2016) Political correctness: how the right invented a phantom enemy. The Guardian. Retrieved from https://www.theguardian.com/us-news/2016/nov/30/politi cal-correctness-how-the-right-invented-phantom-enemy-donald-trump [Accessed 30 November 2016].

Wheeller B (1994) Ego tourism, sustainable tourism and the environment: A symbiotic, symbolic or shambolic relationship? In AV Seaton (ed) Tourism: The State of the Art, 647-654. Chichester: Wiley.

Wheeller B (1993) Sustaining the ego. Journal of Sustainable Tourism 1(2): 121-129.

Wheeller B (2007) Sustainable mass tourism: more smudge than nudge. The canard continues. Tourism Recreation Research 32: 73-75.

Wheeller B (2005) Ecotourism/egotourism and development. In CM Hall, S Boyd (eds) Nature-Based Tourism in Peripheral Areas, 263-272. Clevedon: Channelview publications.

Wierlemann S (2002) Political Correctness in den USA und in Deutschland. Berlin: Erich Schmidt Verlag.

Willis E (1992) No More Nice Girls: Countercultural Essays. Hanover: Wesleyan University Press. 